\title{
Penerapan Media Video Animasi Bencana Alam Gunung Berapi ( BELAGUPI) dengan Model Pembelajaran STAD
}

\author{
Clarita Andriyana Cahyani1 ${ }^{*}$, Mei Fita Asri Untari², Asep Ardiyanto ${ }^{3}$ \\ 123 Jurusan Pendidikan Guru Sekolah Dasar, Fakultas Ilmu Pendidikan Universitas PGRI Semarang
}

\begin{abstract}
Abstrak
Penelitian ini di latar belakangi oleh aktifitas peserta didik dan hasil belajar yang belum mencapai KKM. Tujuan penelitian ini adalah untuk mengkaji penerapan media video animasi Bencana Alam Gunung Berapi (BELAGUPI) dengan model

Kata Kunci:

Mitigasi Bencana, Media Animasi, STAD pembelajaran STAD dapat diterapkan pada peserta didik kelas V SD N Mranggen 02 Kabupaten Magelang. Penelitian ini adalah penelitian kuantitatif dengan menggunakan desain Pra-Experimental Designs (modesigns) rancangan One-Group Pretest-Posttest Designs. Populasi dalam penelitian ini adalah seluruh peserta didik kelas V di SD N Mranggen 02 Kabupaten Magelang. Hasil uji ketuntasan belajar posttest menunjukkan bahwa hasil belajar peserta didik menggunakan media video animasi BELAGUPI dengan model pembelajaran STAD mencapai presentase klasikal sebesar 91\% dengan rata-rata nilai posttest 74,77 dan kriteria ketuntasan minimum (KKM) 70, diperoleh thitung 14,79 dengan $n=22$, dan tabel 2,07. Berdasarkan kriteria pengujian diperoleh thitung $>t_{\text {tabel }}$ yaitu 14,79 $>2,07$ sehingga H0 ditolak. Kesimpulannya penerapan media video animasi BELAGUPI dengan model pembelajaran STAD efektif terhadap hasil belajar peserta didik kelas V SD N Mranggen 02 Kabupaten Magelang.
\end{abstract}

\footnotetext{
Abstract

This research is motivated by the activities of students and learning outcomes that have not yet reached the KKM. The purpose of this study was to determine the Application of Volcanic Natural Disaster Animation Video Media (BELAGUPI) with the

Keywords:

Disaster Mitigation, Animation Media, STAD STAD Learning Model can be applied to fifth grade students of SDN Mranggen 02 Magelang Regency. This research is a quantitative study using Pre-Experimental Designs (modesigns) design of One-Group Pretest-Posttest Designs. The population in this study were all fifth grade students at SDN Mranggen 02 Magelang Regency. Posttest learning completeness test results showed that the learning outcomes of students using BELAGUPI animation video media with the STAD learning model reached a classical percentage of $91 \%$ with an average posttest score of 74.77 and a minimum completeness criterion (KKM) of 70, obtained by 14.79 with $n=22$, and table 2.07. Based on the test criteria obtained tcount $>$ ttable ie 14.79> 2.07 so that $\mathrm{HO}$ is rejected. The conclusion is the application of BELAGUPI animation video media with STAD learning model is effective on the learning outcomes of students in class V SDN Mranggen 02 Magelang Regency.
}

\footnotetext{
* Corresponding author.

E-mail Addresses: clarita.andriana@gmail.com (Clarita Andriyana Cahyani)
} 


\section{PENDAHULUAN}

Mengingat Indonesia merupakan negara yang memiliki banyak bencana alam yang setiap tahun terjadi, salah satunya bencana gunung meletus. Ada beberapa gunung yang masih aktif di Indonesia seperti Gunung Agung di Bali, Gunung Krakatau di Banten, Gunung Bromo di Jawa Timur, Gunung Merapi di Jawa Tengah, dan masih banyak lagi. Dunia pendidikan memegang peranan penting dalam kemajuan suatu bangsa. Melalui jalur pendidikan menghasilkan generasi-generasi penerus bangsa yang berkualitas dan dapat melanjutkan kepemimpinan suatu bangsa. Pendidikan dapat diperoleh dengan berbagai cara, salah satunya pendidikan di sekolah. Sekolah merupakan lembaga pendidikan formal yang secara sistematis melaksanakan program bimbingan, pembelajaran, dan pelatihan dalam rangka membantu peserta didik supaya mampu mengembangkan potensi yang dimiliki secara optimal, baik yang mencakup aspek moral, intelektual, emosional, sosial, maupun fisik-motoriknya.

Menurut Undang-Undang No. 24 tahun 2007 Pasal 1 Ayat 1 bencana adalah peristiwa atau rangkaian peristiwa yang mengancam dan mengganggu kehidupan dan pengidupan masyarakat yang disebabkan, baik oleh faktor alam dan/atau faktor non alam maupun faktor manusia sehingga mengakibatkan timbulnya korban jiwa manusia, kerusakan lingkungan, kerugian harta benda, dan dampak psikologis. Berdasarkan pengertian tersebut dapat diketahui bahwa bencana alam merupakan suatu hal yang dapat menganggu aktivitas baik manusia, hewan, dan tumbuhan, serta merusak lingkungan sekitar. Bahkan memberikan dampak psiklogis bagi manusia berupa rasa trauma. Bencana alam yang terjadi mengakibatkan ketidak seimbangan ekosistem lingkungan dan banyaknya bangunan rusak sehingga mengakibatkan kerugian ekonomi yang cukup besar. Selain lokasi Indonesia yang berada di wilayah dengan aktivitas tektonik yang banyak bencana alam yang terletak di wilayah yang padat penduduk mengakibatkan korban jiwa dan kerusakan yang besar pula.

Berdasarkan penelitian Untari, dkk (2018) Mitigasi bencana harus dikenalkan sejak dini, supaya peserta didik memilliki pengetahuan mengenai bencana alam dan mitigasi bencana. Di SD N Jekurang 02 Srumbung juga menyarankan agar media yang menarik dan interaktif untuk menanamkan mitigasi bencana dan guru perlu mengintegrasikan materi kebencanaan dalam pembelajaran.

Berdasarkan hasil pengamatan di SD N Mranggen 02 Kabupaten Magelang yang berada di lereng Gunung Merapi dan termasuk KRB (Kawasan Rawan Bencana) terdapat permasalahan yaitu belum diterapkannya pembelajaran mitigasi bencana secara spesifik di kelas, pembelajaran belum berpusat pada peserta didik, dan kurangnnya penggunaan media serta model pembelajaran yang menarik. Menurut hasil wawancara dengan guru kelas V, beliau mengatakan jika di SD N Mranggen 02 Kabupaten Magelang belum menerapkan pengajaran mitigasi bencana dalam pembelajaran di kelas. Namun sudah pernah ada sosialisasi di kecamatan yang melibatkan perwakilan guru dan peserta didik untuk mengikuti sosialisasi mitigasi bencana yang meliputi KRB.

Menurut penelitian Suarmika dan Erdi (2017) dalam jurnalnya pendidikan menjadi salah satu sarana yang efektif untuk mengurangi resiko bencana dengan memasukkan materi pelajaran tentang bencana alam sebagai pelajaran wajib bagi setiap siswa di semua tingkatan, terutama di sekolah-sekolah yang berada di wilayah resiko banjir bencana. Kurikulum yang berbasis kearifan lokal, diharapkan dapat diterima dan dapat dengan mudah dipahami oleh siswa.

Menurut Munir (2013:289) istilah video berasal dari bahasa latin yaitu dari kata vidi atau visum yang artinya melihat atau mempunyai daya penglihatan. Dalam Kamus Bahasa Indonesia video adalah teknologi pengirim sinyal elektronik dari suatu gambar bergerak. Video adalah teknologi penangkap, perekaman, pengolahan, penyimpanan, pemindahan dan perekontruksian urutan gambar diam dengan menyajikan adegan-adegan dalam gerak secara elektonik.

Menurut Reiber (dalam Munir 2013:317-318) Animasi berasal dari bahasa latin yaitu "animasi" yang berarti jiwa, hidup, semangat. Selain itu animasi juga berasal dari kata animation yang berasal dari kata dasar to anime didalam kamus Indonesia Inggris berarti menghidupkan. Secara umum aimasi merupakan suatu kegiatan menghidupkan, menggerakkan benda mati. Suatu benda mati diberi dorongan, kekuatan, semangat dan emosi untuk menjadi hidup atau hanya berkesan hidup. Animasi bisa diartikan sebagai gambar yang memuat objek yang seolah-olah hidup, disebabkan oleh kumpulan gambar itu berubah beraturan dan bergantian ditampilkan. Objek dalam gambar bisa berupa tulisan, bentuk benda, warna atau spesial efek.

Dari uraian diatas, peneliti memberi solusi dengan menerapkan media video animasi BELAGUPI dengan model pembelajaran STAD pada peserta didik kelas V SD N Mranggen 02 Kabupaten Magelang untuk mengatasi permasalahan tersebut. Tujuan penelitian ini adalah untuk mengkaji penerapan media video animasi BELAGUPI dengan model pembelajaran STAD dapat diterapkan pada peserta didik kelas V. Dengan menerapkan media video animasi BELAGUPI peserta didik akan tertarik mengikuti pembelajaran dengan penayangan video animasi yang berisi pengetahuan mengenai mitigasi bencana terutama bencana 
gunung meletus. Selain itu penggunaan model pembelajaran STAD juga cocok diterapkan saat pembelajaran karena peserta didik lebih senang belajar bersama teman sebayanya secara berkelompok. Melalui media video animasi BELAGUPI dan model pembelajaran STAD membantu peserta didik mengingat dan memahami materi mitigasi bencana sehingga mempengaruhi hasil belajar peserta didik.

Keunggulan pembelajaran koopertatif tipe STAD terletak pada langkah-langkah pembelajaran yang diterapkan. Penerapan model pembelajaran kooperatif tipe STAD diharapkan mampu meningkatkan hasil belajar siswa. Keunggulan pembelajaran kooperatif tipe STAD yaitu siswa bekerja dalam kelompok sehingga siswa dapat memahami konsep materi yang ada dengan bantuan teman kelompok mereka. Hal ini diperkuat dalam hasil penelitian Asdar (2009) pembelajaran kooperatif tipe STAD, bekerja dalam kelompok sehingga siswa dapat menumbuhkan kemauan kerja sama, berpikir kritis, termotivasi, bertanggung jawab terhadap kelompok. Siswa memiliki kemampuan untuk membantu teman dan terhadap diri sendiri dalam mengikuti kuis nantinya guna mencapai suatu tujuan yaitu mendapatkan penghargaan tim yang super. Adanya evaluasi, siswa mampu merangkum pelajaran yang diterima dari penjelasan guru maupun hasil kerja kelompok yang dilakukan. Guru mengevaluasi hasil belajar tentang materi yang telah dipelajari dimana siswa tidak diperbolehkan bekerja sama (Wardana, 2017).

\section{METODE PENELITIAN}

Penelitian ini dilakukan di SD N Mranggen 02 Kabupaten Magelang pada kelas V tahun ajaran 2019/2020, dengan populasi peserta didik berjumlah 22. Penelitian ini dilaksanakan selama 3 hari. Pada hari pertama peneliti memberikan soal pretest dengan materi mitigasi bencana yang sebelumnya belum diterapkan di sekolah tersebut. Hari kedua peneliti mengajar dengan menggunakan media video animasi BELAGUPI dengan model pembelajaran STAD. Hari ketiga peneliti memberikan soal posttest untuk mengetahui pemahaman materi mitigasi bencana yang sudah diterapkan pada hari kedua.

Metode yang digunakan yaitu metode penelitian kuantitatif menggunakan desain PraExperimental Designs (modesigns) rancangan One-Group Pretest-Posttest Designs. Dalam penelitian ini kelas diberikan pretest untuk mengetahui kondisi awal, selanjutkan kelas diberi perlakukan berupa penerapan model video animasi BELAGUPI dengan model pembelajaran STAD mengenai materi mitigasi bencana. Selanjutkan kelas diberikan posttest untuk mengetahui apakah penerapan media video animasi BELAGUPI dengan model pembelajaran STAD efektif terhadap hasil belajar peserta didik.

Menurut Sugiyono (2017:3) metode penelitian adalah cara ilmiah untuk mendapatkan data dengan tujuan dan kegunaan tertentu. Sedangkan metode penelitian pendidikan dapat diartikan sebagai cara ilmiah untuk mendapatkan data yang valid dengan tujuan dapat ditemukan, dikembangkan dan dibuktikan suatu pengetahuan tertentu sehingga pada gilirannya dapat digunakan untuk memahami, memecahkan, dan mengantisipasi masalah dalam bidang pendidikan (Sugiyono 2017:7).

\section{$\mathbf{O}_{1} \times \mathbf{O}_{2}$}

Gambar 1. Rancangan Desain Penelitian

Keterangan:

$\mathrm{O}_{1} \quad$ = nilai pretest (sebelum diberi perlakuan menggunakan model Project Based Learning)

$\mathrm{O}_{2} \quad$ = nilai postest (setelah diberi perlakuan menggunakan model Project Based Learning)

$\mathrm{X}=$ perlakuan (pembelajaran menggunakan model Project Based Learning)

Teknik pengumpulan data dalam penelitian ini adalah wawancara, tes, dan dokumentasi. Wawancara dilakuan bertujuan untuk mendapatkan informasi kondisi awal sebelum dilakukan penelitian. Tes dilakukan untuk mengukur kemampuan peserta didik sebelum dan sesudah diberi perlakuan menggunakan media dan model pembelajaran. Dokumentasi dilakukan untuk mendapatkan data-data mengenai RPP, nama peserta didik, dan data-data lainnya yang dieprlukan dalam penelitian,

Teknik analisis data peneliti menggunakan uji ketuntasan belajar, uji normalitas, uji-t. uji normalitas digunakan untuk mengetahui data yang berdistribusi normal. Uji ketuntasan belajar digunakan untuk mengetahui tuntas tidaknya hasil belajar peserta didik dengan tolak ukur yang telah ditentukan sekolah (KKM). 


\section{ANALISIS DAN PEMBAHASAN}

Data penelitian ini terdiri dari data hasil pretest dan posttest. Pretest merupakan tes awal untuk mengetahui kemampuan awal peserta didik pada proses pembelajaran sebelum adanya perlakuan. Setelah diberi perlakuan dengan menerapkan media video animasi BELAGUPI dengan model pembelajaran STAD, kemudian peneliti memberikan posttest yang merupakan tes akhir selain untuk mengetahui pemahaman peserta didik dalam materi mitigasi bencana ala gunung merapi dan setelah diberi perlakuan.

\section{A. Hasil Nilai Pretest dan Posttest}

Tabel 1. Data Nilai Pretest dan Posttest

\begin{tabular}{lccc}
\hline \multicolumn{1}{c}{ Jenis Tes } & Nilai Tertinggi & Nilai Terendah & Rata-Rata \\
\hline Pretest & 80 & 35 & 53,4 \\
Posttest & 90 & 60 & 74,7 \\
\hline
\end{tabular}

Berdasarkan Tabel 1 dapat dilihat bahwa selisih nilai pretest tertinggi dan terendah berbeda jauh.Nilai tertinggi yaitu 80, sedangkan nilai terendahnya 35. Nilai rata-rata saat pretest yaitu 53,4 terdapat 2 peserta didik yang tuntas. Hal tersebut menunjukkan bahwa nilai pada pretest masih rendah dan belum mencapaiKriteria Ketuntasan Minimum (KKM) yaitu 70.

Perbandingan antara nilai pretest yang dilakukan sebelum pembelajaran dengan nilai posttest yang diperoleh pada akhir pembelajaran menggunakan perlakuan dengan model pembelajaran STAD berbantu media video animasi BELAGUPI mengalami kenaikan. Seperti yang terlihat pada tabel data nilai pretest dan posttes, nilai posttest tertinggi yaitu 90 dan terendah 60 dengan nilai rata-rata 74,7 terdapat 4 peserta didik yang tidak tuntas dan 18 peserta didik tuntas. Hal tersebut menunjukkan bahwa terdapat peningkatan dari nilai pretest sebelum diberi perlakuan dengan nilai posttest sesudah diberi perlakuan dengan model pembelajaran STAD berbantu media video animasi BELAGUPI. Kenaikan hasil belajar materi mitigasi bencana alamgunung berapi pada peserta didik ditandai dengan nilai rata-rata posttest lebih besar dari nilai pretest yaitu 74,7 > 53,4.

\section{B. Analisis Data}

Tabel 2. Hasil Uji Normalitas Data Nilai Pretest

\begin{tabular}{lcc}
\hline & Data & Pretest \\
\hline L $_{\text {hitung }}$ & & 0,13043 \\
L $_{\text {tabel }}$ & 0,183 \\
Kriteria & Berdistribusi Normal \\
\hline
\end{tabular}

Berdasarkan Tabel 2 hasil pengujian normalitas data Pretest diperoleh nilai $\mathrm{L}_{0 \text { hitung }}$ 0,13043 dengan taraf signifikan $5 \% \mathrm{n}=22$ maka diperoleh $\mathrm{L}_{0 \text { tabel }} 0,183$. Karena $\mathrm{L}_{0 \text { hitung }}<$ dari $\mathrm{L}_{0 \text { tabel }}$ maka normal. Jadi data nilai Pretest menunjukkan bahwa sampel berasal dari populasi berdistribusi normal

Tabel 3. Hasil Uji Normalitas Data Nilai Posttest

\begin{tabular}{lcc}
\hline & Data & Posttest \\
\hline L $_{0 \text { hitung }}$ & & 0,115036 \\
$\mathrm{~L}_{0 \text { tabel }}$ & 0,183 \\
Kriteria & Berdistribusi Normal \\
\hline
\end{tabular}

Berdasarkan Tabel 3 hasil pengujian normalitas data nilai Posttest diperoleh nilai $\mathrm{L}_{0 \text { hitung } 0,115036}$ dengan taraf signifikakn $5 \% \mathrm{n}=22$, maka diperoleh $\mathrm{L}_{0 \text { tabel }} 0,183$. Karena $\mathrm{L}_{0 \text { hitung }}<$ dari $\mathrm{L}_{0 \text { tabel }}$ maka normal. Jadi data nilai Posttest menunjukkan bahwa sampel berasal dari populasi berdistribusi normal.

\section{Uji Hipotesis}

Uji hipotesis dalam penelitian ini menggunakan uji t, digunakan untuk mengkaji hipotesis penelitian sebelum diberi perlakuan dan sesudah diberi perlakuan. Kriteria pengujian $\mathrm{H}_{\mathrm{a}}$ diterima apabila $t_{\text {hitung }}>t_{\text {tabel }}$ dengan $\mathrm{db}=\mathrm{n}-1$ dan taraf signifikan $5 \%$. Setelah dilakukan analisis data nilai hasil belajar 
pada aspek kognitif diperoleh rata-rata untuk pretest sebesar 53,4 dan posttest sebesar 74,7 dengan $\mathrm{N}=$ 22 jadi $\mathrm{db}=\mathrm{N}-1=20-1=21$ yang diperoleh $\mathrm{t}_{\text {hitung }}=14,79560441$ dengan taraf signifikan $5 \%$ didapat nilai $t_{\text {tabel }}=2,074$. Jadi 14,79560441> 2,074 maka $\mathrm{H}_{\mathrm{a}}$ diterima artinya Penerapan Media Vidio Animasi BELAGUPI (Bencana Alam Gunung Berapi) denga model pembelajaran STAD (Student Teams Achievement Divisions) efektif pada peserta didik kelas V SD N Mranggen 02 Kabupaten Magelang.

\section{Ketuntasan Hasil Belajar}

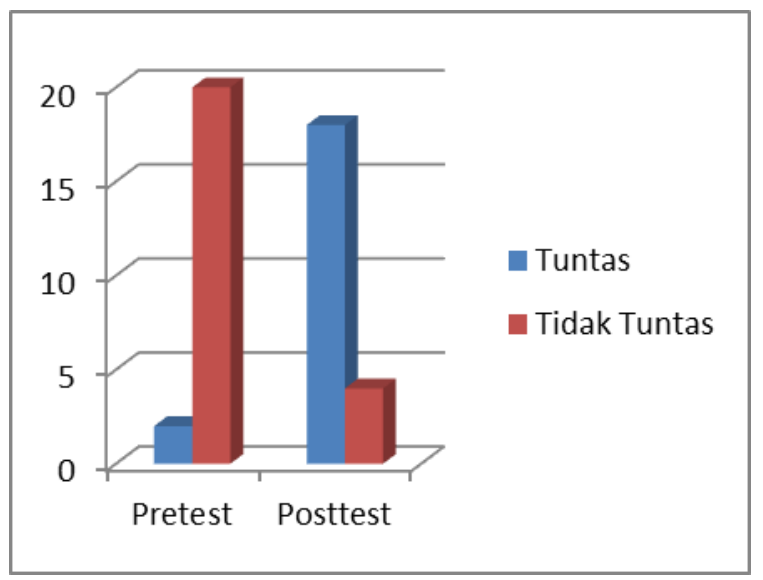

Gambar 1. Diagram Hasil Nilai Perhitungan Ketuntasam Belajar Individu.

Berdasarkan Gambar 1 dapat dilihat hasil ketuntasan belajar peserta didik pada hasil pretest peserta didik yang tuntas 2 peserta didik dan tidak tuntas 20 peserta didik, sedangkan pada hasil posttest terdapat 18 peserta didik yang tuntas dan 4 peserta didik tidak tuntas. Dengan demikian, ketuntasan hasil belajar peserta didik lebih banyak dalam hasil posttest setelah diberi perlakuan dengan menerapkan media video animasi BELAGUPI (Bencan Aalam Gunung Berapi) dengan model pembelajaran STAD (Student Teams Achievement Divisions).

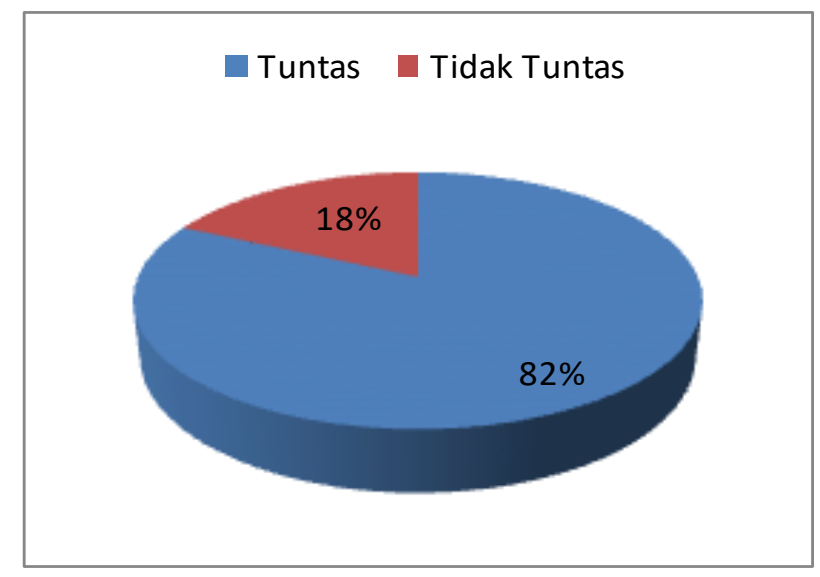

Gambar 2. Diagram Ketuntasan Belajar Klasikal

Bedasarkan Gambar 2 ketuntasan belajar klasikal posttest mencapai $82 \%$ dan 18\% peserta didik tidak tuntas. Dengan demikian, hasil posttest dapat dikatakan tuntas secara klasikal karena $>70 \%$ peserta didik tuntas belajar.

Dari hasil observasi dan wawancara diperoleh informasi bahwa di SD N Mranggen 02 Kabupaten Magelang sudah adanya materi mitigasi bencana akan tetapi peserta didik kurang memahami jika pembelajaran tersebut merupakan materi mitigasi bencana pada pembelajaran tematik. Karena wilayah sekolah tersebut dekat dengan Gunung Merapi dan bisa dikatakan berada di lereng Gunung Merapi jadi peserta didik SD N Mranggen 02 harus dibekali mitigasi bencana atau penanggulangan bencana untuk mengatasi sewaktu-waktu jika Gunung Merapi meletus karena status Gunung Merapi masih aktif. Pernah diadakanya sosialisasi mitigasi bencana terhadap Sekolah Dasar yang termasuk KRB (Kawasan Rawan 
Bencana), namun tidak semua peserta didik ikut serta dalam sosialisasi tersebut hanya perwakilan peserta didik dan guru setiap sekolah.

Rancangan dan desain penelitian ini menggunakan desain Pra-Experimental Designs (nondesigns) dengan menggunakan rancangan One-Group Pretest-Posttest Design dimana dalam penelitian ini terdapat pretest dan posttest. Berdasarkan data yang diperoleh sebelum diberi perlakuan rata rata pada nilai pretest adalah 53,4 dimana peserta didik yang tuntas sebenyak 2 peserta didik dan belum tuntas sebanyak 20 peserta didik. Sedangkan rata rata pada nilai posttest adalah 74,7 terdapat 18 peserta didik yang tuntas dan 4 peserta didik belum tuntas. Hal tersebut menunjukkan bahwa adanya peningkatan sebelum diberi perlakuan dan setelah diberi perlakuan. Kemudian peneliti juga melakukan uji persyaratan analisis data baik pretest maupun posttest yaitu uji normalitas menggunakan uji lilliefors.

Hasil perhitungan nilai pretest menggunakan uji normalitas yang dilakukan oleh peneliti diperoleh kesimpulan bahwa kelas V SD N Mranggegn 02 Kabupaten Magelang berdistribusi normal karena nilai $\mathrm{L}_{0}<\mathrm{L}_{\text {tabel }}$ yaitu $0,183<0,13043$ artinya data berdistribusi normal dengan $\mathrm{n}=22$ dan taraf nyata $\alpha=0,05$. Setelah itu peneliti juga menghitung hasil nilai posttest menggunakan uji normalitas yang diperoleh kesimpulan bahwa kelas V SD N Mranggen 02 Kabupaten Magelang berdistribusi normal karena nilai $\mathrm{L}_{0}<\mathrm{L}_{\text {tabel }}$ yaitu 0,183 $<0,115036$ artinya data berdistribusi normal dengan $\mathrm{n}=22$ dan taraf nyata $\alpha=$ 0,05 . Setelah dilakukan uji normalitas untuk mengetahui apakah data tersebut normal atau tidaknya, selanjutnya peneliti melakukan uji t. Uji t dalam penelitian ini digunakan untuk mengkaji hipotesis penelitian sebelum diberi perlakuan dan setelah diberi perlakuan. Uji t yang digunakan dalam penelitian ini adalah Paired Sample t-test dengan kriteria $\mathrm{H}_{\mathrm{a}}$ diterima apabila $t_{\text {hitung }}>\mathrm{t}_{\text {tabel }}$ dan $\mathrm{H}_{\mathrm{a}}$ ditolak apabila $t_{\text {hitung }}$ $<t_{\text {tabel }}$ dengan $\mathrm{db}=\mathrm{n}-1$ dan taraf signifikan 5\%. Pada penelitian ini diperoleh 14,79560441 > 2,074 artinya $t_{\text {hitung }}>t_{\text {tabel }}$ maka $H_{a}$ diterima artinya Penerapan Media Video Animasi BELAGUPI Dengan Model Pembelajaran STAD efektif pada peserta didik kelas V SD N Mranggen 02 Kabupaten Magelang.

Penelitian yang mengkaji tentang penerapan media digital berupa video animasi telah banyak dilakukan. Berdasarkan hasil penelitian yang dilaksanakan menunjukkan bahwa penggunaan media digital berupa video animasi dapat meningkatkan pemahaman peserta didik. Sejalan dengan penelitian Supryadi, dkk (2017) penelitian dilakukan dengan tujuan untuk mengetahui peningkatan hasil belajar IPA siswa kelas V SDN No.2 Bengkel, Kecamatan Busungbiu, Kabupaten Buleleng Tahun 2012/2013 setelah Hasil penelitian menunjukkan terjadi peningkatan belajar siswa pada pembelajaran IPA sebesar 67,9\% (kategori sedang) pada siklus I, kemudian meningkat menjadi 82,8\% pada siklus II (kategori tinggi). Ini menunjukkan bahwa terjadi peningkatan hasil belajar sebesar $14,9 \%$ dari siklus I ke siklus II. Berdasarkan hal tersebut, maka disimpulakan bahwa media video animasi pembelajaran terbukti efektif secara signifikan dapat meningkatkan hasil belajar IPA siswa kelas V di SDN No.2 Bengkel, Kecamatan Busungbiu, Kabupaten Buleleng. Sejalan dengan penelitian Supriyadi, dkk, menurut Agustien, dkk (2018) daya tarik pendidik terhadap media video animasi dua dimensi diperoleh nilai presentase sebesar $88 \%$ termasuk dalam kategori sangat menarik, daya tarik peserta didik terhadap media video animasi dua dimensi pada uji kelompok kecil 84\% kategori menarik, dan daya tarik peserta didik terhadap media video animasi dua dimensi pada uji kelompok besar $87 \%$ kategori sangat menarik.

Berdasarkan hasil penelitian menunjukkan bahwa Penerapan Media Video Animasi BELAGUPI Dengan Model Pembelajaran STAD efektif pada peserta didik kelas V SD N Mranggen 02 Kabupaten Magelang mengalami peningkatan dari yang awalnya diberi soal Pretest peserta didik yang tuntas yaitu 2 dan yang tidak tuntas yaitu 20 dengan rata-rata nilai 53,4. Saat diberi soal Posttest peserta didik yang tuntas yaitu 18 dan yang tidak tuntas yaitu 4 dengan nilai rata-rata 74,7. Rata-rata nilai pretest dan nilai posttest mengalami peningkatan sebesar 21,3. Hal tersebut menunjukkan bahwa adanya peningkatan sebelumdiberi perlakuan dan sesudah diberi perlakuan.

\section{KESIMPULAN}

Berdasarkan hasil pelitian dan pembahasaan, dapat disimpulkan bahwa adanya pengaruh terhadap penerapan media video animasi BELAGUPI (Bencana Alam Gunung Berapi) dengan model pembelajaran STAD pada peserta didik kelas V SD N Mranggen 02 Kabupaten Magelang terhadap hasil belajar pada materi mitigasi bencana. Hal ini berdasarkan hasil penelitian menggunakan uji $t$ diperoleh $t_{\text {hitung }}>\mathrm{t}_{\text {tabel }}$ yaitu 14,79560441 $>2,074$ dengan taraf signifikan 5\%, maka $\mathrm{H}_{0}$ ditolak dan $\mathrm{H}_{\mathrm{a}}$ diterima artinya penerapan media video animasi BELAGUPI (Bencana Alam Gunung Berapi) dengan model pembelajaran STAD efektif diterapkan padapeserta didik kelas V SD N Mranggen 02 Kabupaten Magelang.

Berdasarkan hasil pelitian dan pembahasaan, maka saran yang dapat diajukan adalah media video animasi BELAGUPI dapat dijadikan media yang dapat membantu guru dalam menyampaikan materi dan memudahkan peserta didik memahami materi pembelajaran, peserta didik harus berperan aktif saat pembelajaran terutama saat bekerja kelompok supaya tugas yang dikerjakan dapat berjalan dengan 
maksimal, peneliti lain dapat menggunakan model pembelajaran STAD dan media video animasi BELAGUPI sebagai referensi untuk meningkatkan proses pembelajaran.

\section{DAFTAR PUSTAKA}

Agustien, Relis, dkk. 2018. Pengembangan Media Pembelajarn Animasi Dua Dimensi Situs Pekauman di Bondowoso Dengan Model Addie Mata Pelajran Sejarah Kelas X IPS. Jurnal Edukasi. Vol (1):(22).

Darimi, Ismail. 2017. Teknologi Informasi Dan Komunikasi Sebagai MediaPembelajaran Pendidikan Agama Islam Efektif. Jurnal Pendidikan Teknologi Informasi. Vol (1) : (116).

Imamah, Nurul, Ahmad Ma'ruf.2018. Pengaruh Penerapan Media Videoscribe Untuk Meningkatkan Pemahaman Aqidah Akhlaq Di Mts Darul Ulum Purwodadi. Jurnal Pendidikan Agama Islam. Vol (4) : (88).

Munir. 2013. MULTIMEDIA Konsep dan Aplikasi dalam Pendidikan. Bandung: Alfabeta.

Suarmika, Putu Eka dan Erdi Guna Utama. 2017. Penidikan Mitigasi Bencana di Sekolah Dasar. Jurnal Pedidikan Dasar Indonesia. Vol (2):(2).

Sugiyono. 2018. Metode Penelitian kuantitatif, kualitatif, dan R\&D. Bandung: Alfabeta.

Sunarti, S. R., \&amp; Wardani, S. 2016. Pengembangan Game Petualangan "Si Bolang" Sebagai Media Pembelajaran Tematik Untuk Meningkatkan Motivasi Dan Prestasi Belajar Siswa Kelas V Sekolah Dasar. Jurnal Cakrawala Pendidikan.Vol (5): (58-68).

Supryadi, Eka Pt, dkk. 2013. Penerapan Media Video Pembelajaran Sebagai Aplikasi Pendekatan Contekstual Teaching Learning untuk Meningkatkan Hasil Belajar IPA Siswa Kelas V. Mimbar PGSD UNDIKSHA, ejournal.undiksha.ac.id.

Undang-Undang Republik Indonesia Nomor 20 Tahun 2003 tentang sistem Pendidikan Nasional.Jakarta

Undang-Undang Republik Indonesia Nomor 24 Tahun 2007 Pasal 1 Ayat 1 Tentang Bencana.Jakarta

Untari, dkk. 2018. Pembelajaran Mitigasi Bencana Alam di Sekolah Dasar Lereng Gunung Merapi: Kajian Deskriptif di SD Negeri Jeruk Agung Kecamatan Srumbung Kabupaten Magelang. Prosiding Seminar Nasional.

Wardana, Ika. 2017. Penerapan Model Pembelajaran Kooperatif Tipe Student Team Achivement Division (STAD) untuk Meningkatkan Hasil Belajar Siswa Kelas XI IPA Avogadro SMA Negeri 2 Pangkajene (Studi pada Materi Asam Basa). Jurnal Chemica Vol (18):(1).

Widiyasanti, Margareta, Yulia Ayriza. 2018. Pengembangan Media Video Animasi Untuk Meningkatkan Motivasi Belajar Dan Karakter Tanggung Jawab Siswa Kelas V. Jurnal Pendidikan Karakter. 